\title{
Analysis of the Role of Information Systems Technology in Lecture Learning during the Corona Virus Pandemic
}

\author{
$1^{\text {st }}$ Muqorobin, $2^{\text {nd }}$ Nendy Akbar Rozaq Rais \\ ${ }^{1,2}$ Institut Teknologi Bisnis AAS Indonesia Surakarta \\ ${ }^{1,2}$ Jl. Slamet Riyadi No. 361 Windan, Makamhaji, Kartasura, Sukoharjo, Indonesia \\ 1robbyaullah@gmail.com,2ab.terate@gmail.com
}

\begin{abstract}
At this time the spread of the Corona Covid-19 Virus was sweeping the world, Indonesia was also affected, especially in the world of education where the teaching and learning process was usually carried out face-to-face in the classroom. So as a result of this pendemi the teaching and learning process must be done online. The role of information systems technology is very meaningful in lecture learning. This study aims to analyze a model of campus learning conditions and the role of information system technology in college learning amid the COVID-19 corona virus pandemic at STMIK Sinar Nusantara Surakarta. The research method is to make observations and literature studies to obtain data and information used in research. The results of this study indicate the use of information technology has a very important role in the implementation of online distance learning in the midst of the corona covid 19 virus pandemic, among online online media such as: google classroom, whatsapp, zoom. Of the online learning media, it is proven that Google Classroom: $55.9 \%$ is widely used as media for sharing materials and assignments, while video conferences lectures are the most users of Google Meet as much as: 70.6\%. The results of the analysis of the online learning value are: $44.1 \%$. Based on this data, it shows that the role of information system technology plays an important role and helps in the teaching and learning process amid the Covid-19 corona virus pandemic.
\end{abstract}

Keywords - Analysis, Technology, Information Systems, Corona Virus, Covid-19

\section{INTRODUCTION}

The spread of the Corona Virus is currently sweeping the world, Corona virus is a large family of viruses that cause disease in humans and animals. In humans, it usually causes respiratory infections, from the common cold to serious diseases such as Middle East Respiratory Syndrome (MERS) and Severe Acute Respiratory Syndrome (SARS), to date 213 countries have contracted the corona covid virus 19, (https://infemerging.kemkes.go.id/). In December 2019, cases of mysterious pneumonia were first reported in Wuhan, Hubei Province. The source of the transmission of this case is still unknown, but the first case was linked to a fish market in Wuhan [1]. From 18 December to 29 December 2019, five patients were treated with Acute Respiratory Distress Syndrome (ARDS) (Chin Med J, 2020). From 31 December 2019 to 3 January 2020, this case increased rapidly, marked by the reporting of 44 cases. In less than one month, the disease has spread to various other provinces in China, Thailand, Japan and South Korea[3].

The first COVID-19 was reported in Indonesia on March 2, 2020 in two cases (World Health Organization, 2020). March 31, 2020 data shows that there are 1,528 confirmed cases and 136 cases of death (Ministry of Health of the Republic of Indonesia, 2020). The mortality rate for COVID-19 in Indonesia is $8.9 \%$, this figure is the highest in Southeast Asia (Prasetya, E., 2006). In the case of COVID19, pangolins are suspected of being an intermediate reservoir. The coronavirus strains in pangolins are genomically similar to the bat coronavirus $(90.5 \%)$ and SARS-CoV-2 (91\%) (Zhang T, 2020). The SARS-CoV-2 genome itself has $89 \%$ homology against the ZXC21 bat coronavirus and $82 \%$ against SARS-CoV (Chan JF-W, 2019). Corona Covid 19 virus and is being treated at the Prof. Infectious Diseases Hospital. Dr. Sulianti Saroso, North Jakarta. Furthermore, on Thursday 12 March 2020, Achmad Yurianto, the Government Spokesperson for the
Handling of the Corona Virus (Covid-19), who is also the Director General (Dirjen) for Disease Prevention and Control (P2P), stated that the World Health Organization ( WHO) has determined that the Corona Virus (Covid-19) is a Pandemic so that it signals the whole world to believe this disease can attack anyone and any country in the world, therefore all countries must anticipate and respond and must also be vigilant. And to respond to this, on Sunday, March 15, 2020, President Jokowi appealed to the Indonesian people to remain calm. The President stated "With this condition, it is time for us to work from home, learn from home, worship at home," said President Jokowi when delivering his statement. press at the Bogor Presidential Palace, West Java Province and with President Jokowi's direction, Monday (16/3/2020), the Minister of Education and Culture coordinates learning through an online system or online by getting free assistance from Ruangguru, Zenius, Google, Microsoft, Quipper, Your School and Smart Class. President Jokowi believes that the online or online system will reduce the mobility of students and reduce the spread of Covid-19.

On the other hand, in order to maintain the world of education, it can continue to run well and support the Government in supporting psychological distanting amid the Covid 19 pandemic according to the president's instructions to stay at home, study at home, work at home, worship at home. The Minister of Education and Culture (Mendikbud) followed up on this policy through Circular (SE) Number 4 of 2020 concerning the Implementation of Education Policies in an Emergency Period for the Spread of Covid-19, in this case point 2 which states, the Learning from Home process is carried out with the provisions namely (a) Learning from Home through online / distance learning is implemented to provide meaningful learning experiences for students, without being burdened with demands to complete all curriculum achievements for grade promotion and graduation; (b) Learning from Home can 
International Journal of Computer and Information System (IJCIS)

Peer Reviewed - International Journal

Vol : Vol. 01, Issue 02, August 2020

e-ISSN : 2745-9659

https://ijcis.net/index.php/ijcis/index

focus on life skills education, including regarding the Covid-19 pandemic; (c) Learning from Home activities and assignments may vary between students, according to their respective interests and conditions, including considering gaps in access / learning facilities at home; (d). Evidence or products of Learning from Home activities are given qualitative and useful feedback from the teacher, without being required to give a quantitative score. Maria Van Kerkhove, WHO epidemiologist on March 20, 2020 also added "Today, thanks to advanced technology, we can stay connected in many ways without actually being in the same room.

\section{RESEARCH METHODS}

In collecting data that is useful for completing this research, the researcher uses the following research methods:

a. Observation Method

In this case the researcher sees and studies the problems that exist in the field that are closely related to the object under study, namely the use of information technology in distance learning at STMIK Sinar Nusantara Surakarta, through a questionnaire to obtain data so that it can be processed in the discussion of this study.

b. Literature Study Method

In this case the researcher gets data sources from various sources by collecting supporting references through books, journals, magazines and other sources that support research, this method is used in collecting related data.

\section{RESULT AND ANALYSIS}

In the discussion of this study contains an analysis of the application of information system technology to the online learning process within the scope of the world of education in STMIK Sinar Nusantara lectures. The results of the discussion can be described by the researcher in the following description along with the analysis process of online media which is most widely used in learning:

a. Corona Covid Virus 19

Corona viruses are a large family of viruses that cause disease in humans and animals. In humans, it usually causes respiratory infections, from the common cold to serious illnesses such as Middle East Respiratory Syndrome (MERS) and Severe Acute Respiratory Syndrome (SARS). A new type of Coronavirus that was discovered in humans since the outbreak occurred in Wuhan China, in December 2019, was then named Severe Acute Respiratory Syndrome Coronavirus 2 (SARS-COV2), and causes Coronavirus Disease-2019 (COVID-19), : //covid19.kemkes.go.id)

b. Online Learning

According to Dabbagh and Ritland (Arnesi and Hamid, 2015) online learning is an open and distributed learning system using pedagogical devices (educational aids), which are made possible through the internet and network-based technology to facilitate the formation of learning and knowledge processes through actions and interactions. mean.

c. Information Technology

Haag and Keen (1996): Understanding information technology according to Haag and Keen that information technology is a set of tools that help you work with information and perform tasks related to information processing. 2. Oxford English Dictonary (OED): Information technology is hardware and software and can include networks and telecommunications which are usually in a business or business context. 3. Williams and Sawyer (2003): According to Williams and Sawyer, the notion of information technology is a technology that combines computing (computers) with high-speed communication lines that carry data, voice, and video. 4. Martin (1999): According to Martin, information technology is technology that is not only computer technology (hardware and software) which will be used to process and store information, but includes communication technology to send or disseminate information.

d. Elearning

E-learning is an information and communication technology to enable students to learn anytime and anywhere. E-learning has two types, namely: Synchronous first. Synchronous means at the same time. The learning process occurs at the same time between educators and students. This allows direct interaction between educators and students on line. In its implementation, synchronous training requires educators and students to access the internet simultaneously. Educators provide learning material in the form of papers or presentation slides and students can listen to presentations directly via the internet. Students can also ask questions or comments directly or via the chat window. Synchronous training is a picture of a real class, but is virtual (virtual) and all students are connected via the internet. Synchronous training is often referred to as virtual classrooms. Second, asynchronous means not at the same time. Students can take different learning times with educators providing material. Asynchronous training is popular in e-learning because students can access learning material anywhere and anytime. Students can carry out learning at any time according to a predetermined schedule range. Learning can take the form of reading, animation, simulation, educational games, tests, quizzes and assignments.

e. Kinds of Elearning

The components that make up e-learning are the elearning infrastructure, e-learning systems and applications and e-learning content. E-learning infrastructure is equipment used in e-learning which can be in the form of a Personal Computer ((PC), which is a computer that is privately owned, a computer network, which is a collection of a number of devices in the form of computers, hubs, switches, routers, or other connected network devices. by using certain communication media, the internet which stands for Interconnection Networking which is defined as a computer connected around the world, such as: media devices that combine two or more elements of media consisting of text, graphics, images, photos, audio, video and animation in an integrated manner.

E-learning systems and applications, e-learning systems and applications that are often referred to as Learning Management Systems (LMS), which are software systems that virtualize conventional teaching and learning processes for administration and information. 
International Journal of Computer and Information System (IJCIS)

Peer Reviewed - International Journal

Vol : Vol. 01, Issue 02, August 2020

e-ISSN : 2745-9659

https://ijcis.net/index.php/ijcis/index

\subsection{Zoom Application}

Zoom is a free HD meeting app with videos and screen sharing for up to 100 people, (https://zoom.us/meetings). Zoom is a communication application using video. These applications can be used in a variety of mobile devices, desktop, to telephone and online classroom systems[3]

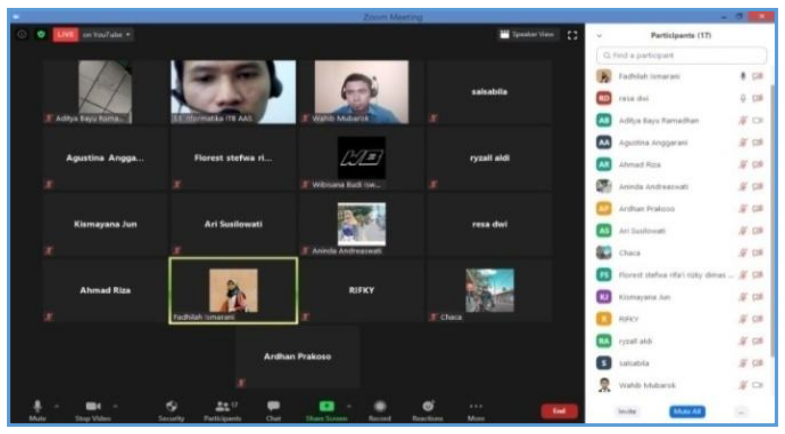

Figure 1. Online Lecture Zoom Implementation

\subsection{Edlink Application}

Sevima EdLink is an android-based application devoted to the world of education in helping lecturers / teachers save time, keep classes organized, and improve communication with students. By downloading Sevima EdLink, lecturers / teachers can share information, lecture / lesson material, and last but not least, lecturers can assign assignments more easily and quickly, because they are only in the palm of their hand. You can download this powerful application on the Playstore for free[4].

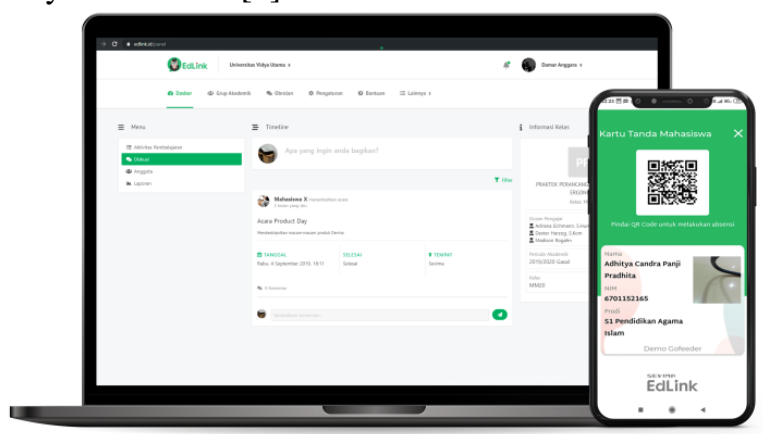

Figure 2. Edlink Application Design

\subsection{Skype Application}

Skype is a communication program with $\mathrm{P} 2 \mathrm{P}$ (peer to peer) technology. This program is a free program (can be downloaded for free) and was created with the aim of providing low-cost, high-quality internet-based voice communication to all people in various parts of the world. Skype users can talk to other Skype users for free, call traditional phones for a fee (skypeOut), receive calls from traditional phones (SkypeIn), and receive voice messages [12]. Skype technology was invented by entrepreneurs Niklas Zennström and Janus Friis, the same people who invented Kazaa and Joost (P2P for television). Skype then competed with existing open VoIP protocols such as SIP, IAX, and H.323. The Skype Group, which was formed in September 2003, was purchased by American internet auction giant e-Bay in September 2005 and is headquartered in Luxembourg, Germany with offices in London, England, Prague, Russia and San Jose, California, USA. Since its launch, Skype has experienced rapid growth both from its popular use and software development, the services offered have varied from free to paid usage. In just a few years in April 2006 Skype had 100 million users.

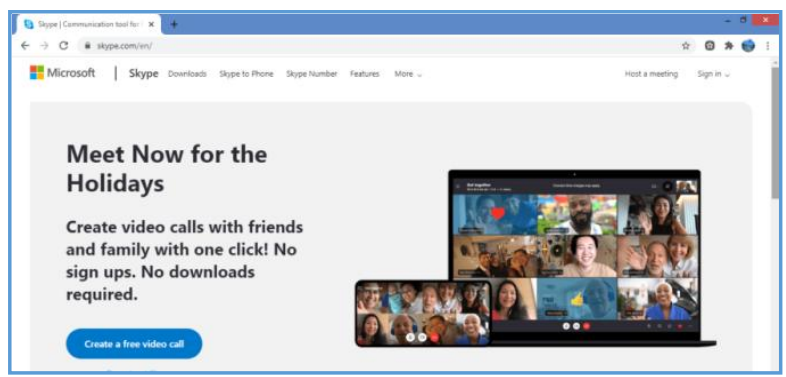

Figure 3. Skype Website page

\subsection{Google Classroom}

Google Classroom or Google's classroom is a mixed learning platform for the scope of education that can make it easier for teachers to create, share and classify each paperless assignment, Afrianti (Yustianti and Novita, 2019).

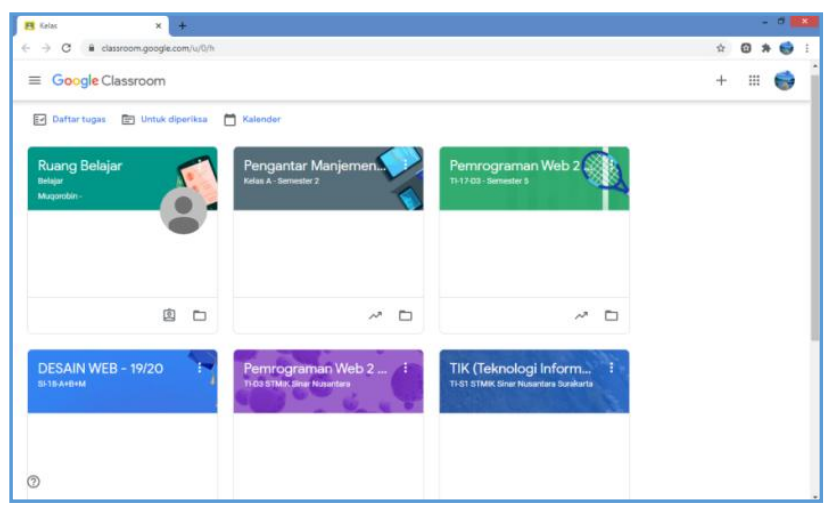

Figure 4. Google Classroom Page

\subsection{Google Meet}

Google Hangouts Meet is a business version of the online video conference or meeting application from Google Hangouts designed for organizations or companies of any size. Its use itself includes mobile and desktop, can be used for free and is fairly simple. Google Hangouts itself is still available for those who haven't moved on, but if your company continues to grow, there's nothing wrong with slowly starting to switch to Google Hangout Meets, whose future looks more promising.

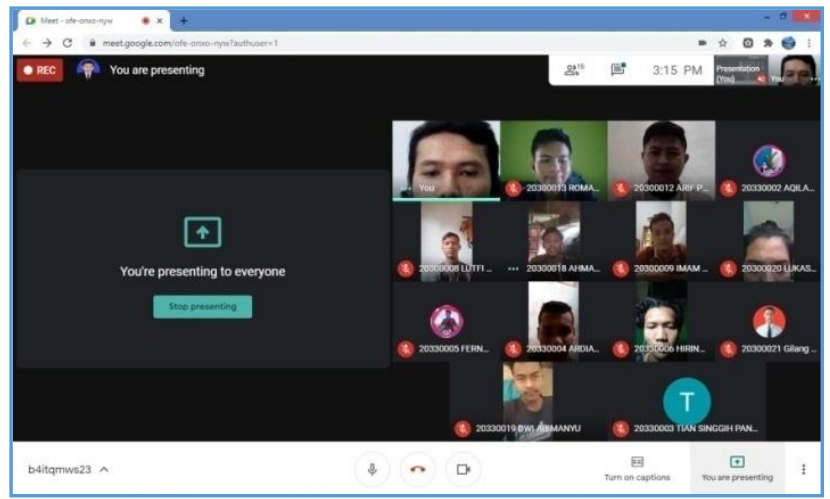

Figure 5. Google Meet page 
International Journal of Computer and Information System (IJCIS)

Peer Reviewed - International Journal

Vol : Vol. 01, Issue 02, August 2020

e-ISSN : 2745-9659

https://ijcis.net/index.php/ijcis/index

\subsection{Whatsapp}

Whatsapp is one of the most popular communication media used today, whats up is an application that is used to make conversations either using text, voice or video. WhatsApp to stay connected with friends and family, anytime, anywhere. WhatsApp is free and offers a simple, safe, reliable messaging and calling experience, available on any phone in the world, (https://www.whatsapp.com /about/?lang=en).

Furthermore, according to Niken, Secretary General of the Ministry of Communication and Informatics, WhatsApp is the application that is most in demand by the public in communicating via the internet. "83\% of our 171 million internet users are WhatsApp users who connect between the community," said Niken in the launch of the educational program "Privacy Literacy and Digital Security" at the Ministry of Communication and Informatics (Kominfo), Jakarta, Monday, 11/18/2020.

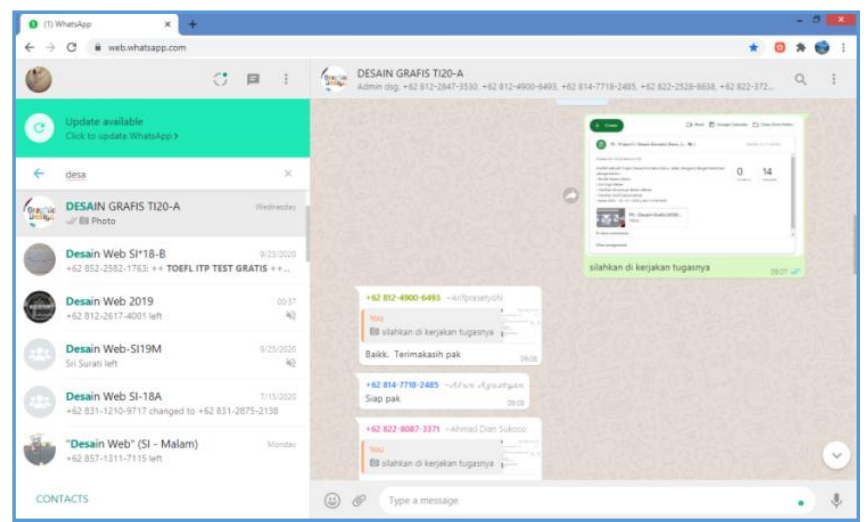

Figure 6. Whatsapp Web

The learning media that is carried out for online lectures are mostly carried out at the STMIK Sinar Nusantara campus, based on the results of the analysis through observations that researchers have made of the online learning media, the results of the analysis can be taken as described as follows:

1. Online vs Offline Lecture Model

In general, students want more lectures to be done offline because the lecture process can be done face-to-face and is easy to communicate. The results of the questionnaire showed that from 34 student respondents more wanted offline lectures, namely $97.1 \%$. but this cannot be done because government regulations restrict face-to-face offline lectures.



Figure 7. Offline vs Online Tuition Comparison

\section{Types of Internet Data Usage}

In general, more internet access users to conduct online lectures, most students access it using data packages from smartphones. The data shows that internet access users with cellphone data packages are $76.5 \%$.

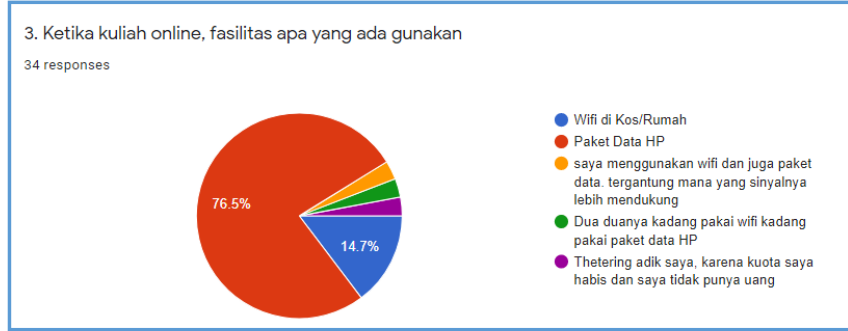

Figure 8. Use of internet access

3. Online Lecture Application to Share Material \& Assignments

The online lecture application most widely used by students is Google Classroom, with 55\% share of material and assignments.



Figure 9. Online Lecture Application Materials \& Assignments

4. Online Lecture Application for Video Conferences

In lectures for the type of video conferences, most students prefer to use Google meet, which is $70.6 \%$.

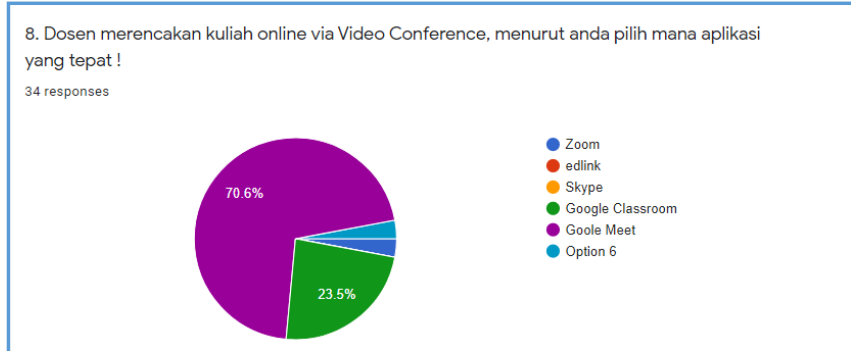

Figure 10. Video Conferences Online Lecture Application

Based on the type of online media that has been carried out by the campus during lectures, the following are the results of assessments carried out by application users regarding the role of information system technology in online lecture learning during the current corona pandemic 
International Journal of Computer and Information System (IJCIS)

Peer Reviewed - International Journal

Vol : Vol. 01, Issue 02, August 2020

e-ISSN : 2745-9659

https://ijcis.net/index.php/ijcis/index

which can produce a point value of 4 (Good) with a percentage weight : $44.1 \%$. This is shown as in Figure 11.



Figure 11. Results of Online Learning Model Assessment

\section{CONCLUSION}

As for this research, it can provide the following conclusions.

\subsection{Conclusion}

The widespread spread of the corona virus has led to the learning process for lectures to be done online online. The role of information systems technologists is the main thing in the solution of the online learning process. Based on the results of research that has been carried out during research on the Analysis of the Role of Information System Technology in Lecture Learning during the Corona Virus Pandemic, it shows online media used in online lectures such as zoom, edlink, skype, Google Classroom, Google Meet, Whatshapp. The results showed that Google Classroom Media was the most popular, namely $55.9 \%$ as a share of material and assignments. Meanwhile, the most popular Video Conferences media is Google Meet: $70.6 \%$. The results of the assessment of the role of information systems technology are in point 4 (Good) as many as: $44.1 \%$. This shows that the role of information system technology in the form of Google Classroom \& Google Meet is the main solution in the online learning process.

\subsection{Suggestions}

This research was conducted based on the results of a questionnaire conducted by researchers only in one campus in Surakarta. For further researchers, they can develop further research by taking data from various places on campus so that it can be used as a comparison of data in research.

\section{REFERENCES}

[1] Rothan HA, Byrareddy SN. The epidemiology and pathogenesis of corona virus disease (COVID-19) outbreak. J Autoimmune, 2020; published online March 3. DOI: 10.1016 / j.jaut.2020.102433.

[2] Ren L-L, Wang Y-M, Wu Z-Q, Xiang Z-C, Guo L, Xu T, et al. Identification of a novel coronavirus causing severe pneumonia in human: a descriptve study. Chin MedJ. 2020; published online February 11. DOI: 10.1097 / CM9.0000000000000722.

[3] Huang C, Wang Y, Li X, Ren L, Zhao J, Hu Y, et al. Clinical features of patents infected with 2019 novel corona virus in Wuhan, China, Lancet. 2020; 395 (10223): 497-506.

[4] World Health Organization. Situaton Report - 42 [Internet]. 2020 [updated 2020 March 02; cited 2020 March 15]. Available from: htps: //www.who.int/docs/default- source/coronaviruse/situation-reports/20200302-sitrep-42covid-19. pdf? sfvrsn $=224$ c1add_2.

[5] Ministry of Health of the Republic of Indonesia. Information on Emerging Infection Ministry of Health RI [Internet]. 2020 [updated 2020 March 30; cited 2020 March 31]. Available from: htps: //infemerging.kemkes.go.id/.

[6] Prasetya, E., 2006, Case Based Reasoning to identify damaged buildings, Thesis, Computer Science Postgraduate Program, Univ. Gadjah Mada, Yogyakarta.

[7] Zhang T, Wu Q, Zhang Z. Probable Pangolin Origin of SARS-CoV-2 Associated with the COVID-19 Outbreak. Curr Biol. 2020; published online March 13. DOI: 10.1016 / j.cub.2020.03.022.

[8] Chan JF-W, Kok K-H, Zhu Z, Chu H, To KK-W, Yuan S, et al. Genomic characterization of the 2019 novel humanpathogenic coronavirus isolated from a patent with atypical pneumonia afer visiting Wuhan. Emerg Microbes Infect. 2020; 9 (1): 221-36. Wallace, V. P., Bamber, J. C. and Crawford, D. C. 2000.

[9] Hartanto, Wiwin. (2016). "Using ELearning as Learning Media", UNEJ Journal, accessed April 20, 2020.

[10] Arnesi Novita and Hamid Abdul. 2015. "The Use of Online Offline Learning Media and Interpersonal Communication Against English Learning Outcomes. Journal of Information \& Communication Technology in Education, Vol. 2, No. 1, June 2015, p-ISSn: 2355-4983; e-ISSN: 2407-7488, accessed April 20, 2020.

[11] Chandra Edy. "Youtube, Interactive Media Image or Media for Conveying Personal Aspirations. Journal of Muara Social Sciences, Humanities, and Arts, Vol. 1, No. 2, October 2017: pp. 406-417, accessed April 21, 2020, the goal is that all teachers, both teachers and lecturers, are still enthusiastic about spreading knowledge

[12] Utomo, I. C., Rokhmah, S., \& Muslihah, I. (2020). Web Based Distribution of Zakat, Infaq, and shodaqoh (Case Study Of Surakarta City Region). International Journal of Computer and Information System (IJCIS), 1(1).

[13] Muqorobin, Muqorobin, Siti Rokhmah, Isnawati Muslihah, and Nendy Akbar Rozaq Rais. "Classification of Community Complaints Against Public Services on Twitter." International Journal of Computer and Information System (IJCIS) 1, no. 1 (2020).

[14] K. Kusrini, E. T. Luthfi, M. Muqorobin and R. W. Abdullah, "Comparison of Naive Bayes and K-NN Method on Tuition Fee Payment Overdue Prediction," 2019 4th International Conference on Information Technology, Information Systems and Electrical Engineering (ICITISEE), Yogyakarta, Indonesia, 2019, pp. 125-130, doi: 10.1109/ICITISEE48480.2019.9003782.

[15] Muqorobin, M., Hisyam, Z., Mashuri, M., Hanafi, H., \& Setiyantara, Y. (2019). Implementasi Network Intrusion Detection System (NIDS) Dalam Sistem Keamanan Open Cloud Computing. Majalah Ilmiah Bahari Jogja, 17(2), 1-9.

[16] Muqorobin, M., Apriliyani, A., \& Kusrini, K. (2019). Sistem Pendukung Keputusan Penerimaan Beasiswa dengan Metode SAW. Respati, 14(1).

[17] Abdullah, Robi W., et al. "Keamanan Basis Data pada Perancangan Sistem Kepakaran Prestasi Sman Dikota Surakarta." Creative Communication and Innovative Technology Journal, vol. 12, no. 1, 2019, pp. 13-21. 